\title{
PENGEMBANGAN MATA KULIAH PRAKTEK KEJURUAN BAGI MAHASISWA JPTM FPTK UPI YANG RELEVAN DENGAN KEBUTUHAN SEBAGAI CALON GURU SMK BIDANG TEKNIK MESIN
}

\author{
Wardaya $^{1}$, Purnawan ${ }^{2}$, Asep H.S ${ }^{3}$.
}

\begin{abstract}
Abstrak. Diantara tujuan pengembangan suatu kurikulum adalah peningkatan relevansi, yaitu adanya kesesuaian antara materi yang dikembangkan dengan kebutuhan pemakainya. Tujuan penelitian ini adalah untuk menghasilkan rancangan pengembangan mata kuliah praktek kejuruan di JPTM FPTK UPI yang dapat meningkatkan relevansi dengan kebutuhan kompetensi guru praktek kejuruan di SMK bidang teknik mesin. Penelitian menggunakan metode deskriftif. Data dikumpulkan melalui studi dokumentasi dan observasi. Sumber data berupa dokumen kurikulum SMK bidang teknik mesin dan kurikulum JPTM FPTK UPI kelompok bidang keahlian Produksi dan Perancangan. Hasil penelitian menunjukkan; (1) Terdapat 19 jenis kompetensi praktek produkif di SMK bidang teknik mesin yang dapat dikelompokkan menjadi 4, yaitu kompetensi gambar, praktek dasar, pemesinan konvensional manual, dan pemesinan konvensional CNC. (2) Telah dihasilkan rancangan pengembangan dan pola sebaran mata kuliah praktek kejuruan yang disusun berdasarkan sekuen isi materi. Sebaran mata kuliah praktek produktif yang dirancang adalah : kompetensi gambar berada pada semester 1,2, dan 5, kompetensi praktek dasar berada pada semester 2,4, dan 5, kompetensi pemesinan konvensional manual berada pada semester 3 dan 4, kompetensi pemesinan konvensional CNC berada pada semester 6 dan 7 .
\end{abstract}

\begin{abstract}
Between development aim a curriculum relevance enhanced, that is existence the relevance between matter that developed with the user need. This watchfulness aim was to produce subject matter development plan of vocational practice at JPTM FPTK UPI that can increase relevance with vocational practice teacher competence need at SMK in mechanical engineering field. Watchfulness uses method descriptive. Data is gathered to pass documentation study and observation. Data source shaped from SMK curriculum document in mechanical engineering field and curriculum of JPTM FPTK UPI on Design and Production skill area group. Watchfulness result shows; (1) found 19 practice competence kinds productive at SMK in mechanical engineering. Competences can be grouped in 4 groups, that is drawing, practice base, machinery conventional manual, and machinery conventional CNC. (2) Produced development and pattern plan of vocational practice subject matter that is composed based on sequence matter contents. Mapping of vocational practice subject matter that designed: picture competence presents in semester 1,2 and 5, practice competences base present in semester 2,4 and 5, competences machinery conventional manual present in semester 3 and 4, competences machinery conventional CNC present in semester 6 and 7.
\end{abstract}

Kata Kunci : Relevansi, praktek kejuruan, guru

\section{PENDAHULUAN}

Secara makro Jurusan Pendidikan Teknik Mesin (JPTM) merupakan elemen dari suatu sistem pendidikan teknologi kejuruan di Indonesia. Institusi ini bertanggung jawab terhadap penyediaan tenaga kependidikan di bidang teknologi kejuruan khususnya pada kelompok teknologi industri. Secara sistemik kualitas out put dipengaruhi secara langsung oleh kualitas proses, dengan demikian kualitas tenaga kependidikan (calon guru SMK) sebagai out put sangat bergantung pada kualitas proses pembelajaran yang dilaksanakan oleh institusi ini.

Sejalan dengan visi dan misi pendidikan teknologi dan kejuruan, program pendidikan dan latihan menjadi salah satu program pokok dalam mencapai standar profesi khususnya peningkatan keterampilan.

Peningkatan keterampilan sangat erat kaitannya dengan kegiatan praktikum. Dari berbagai penelitian yang telah dilakukan, disimpulkan bahwa model pembelajaran praktikum sangat cocok untuk meningkatkan pemahaman mahasiswa terhadap suatu konsep ilmu. Mahasiswa yang melakukan praktikum memiliki hasil belajar yang lebih tinggi dibandingkan dengan mahasiswa yang tidak melakukan praktikum dalam pemahaman suatu konsep (cox dan Junkin III, dalam Ida Hamidah 2004:35)

Kegiatan praktikum bagi mahasiswa di JPTM merupakan salah satu metoda pembelajaran untuk mencapai tiga tujuan secara bersamaan, yatu : meningkatkan keterampilan kognitif, keterampilan afektif, dan keterampilan psikomotorik. Selain itu pembelajaran praktikum cocok untuk melatih proses pembiasaan diri dalam memecahkan persoalanpersoalan teknis secara ilmiah, karena semua keterampilan yang penting dalam praktikum dapat dilatih secara bersamaan. Dalam waktu selanjutnya keterampilan-keterampilan tersebut merupakan bekal yang akan bermanfaat bagi mahasiswa untuk mencapai kompetensi, baik sebagai ahli teknik

494

${ }^{1}$ Drs. Wardaya, M.Pd adalah Dosen Jurusan Pendidikan Teknik Mesin FPTK UPI

${ }^{2}$ Purnawan, S.Pd., MT adalah Dosen Jurusan Pendidikan Teknik Mesin FPTK UPI

${ }^{3}$ Asep Hadian Sasmita, S.Pd. Dosen Jurusan Pendidikan Teknik Mesin FPTK UPI 
maupun sebagai guru di bidang teknik mesin. Mengingat kegiatan praktikum merupakan kegiatan yang sangat strategis, maka harus dioptimalkan baik dalam perencanaan, pelaksanaan maupun hasilnya.

Penelitian ini dilatarbelakangi oleh kenyataan-kenyataan kurang optimalnya program kegiatan praktikum di JPTM yang terjadi selama ini. Ditinjau dari segi perencanaan, diantara indikatornya adalah sebaran mata kuliah praktik pada kurikulum yang disusun kurang mengkerucut pada suatu bidang keahlian (kompetensi). Hal ini kemungkinan disebabkan tidak adanya data empirik berkaitan dengan relevansi kurikulum yang disusun dengan tuntutan standar guru SMK bidang teknik mesin. Rendahnya relevansi akan berdampak terhadap kurang siapnya lulusan memasuki dunia kerja yang berarti akan menambah jumlah pengangguran.

Ditinjau dari segi pelaksanaan, terlihat bahwa kegiatan praktikum antara satu mata kuliah dengan mata kuliah lain berjalan sendiri-sendiri. Hal ini menunjukkan ketidakjelasan tujuan akhir dari pelaksanaan kegiatan praktikum tersebut. Selain dipandang kurang menimbulkan pengalaman bagi mahasiswa pola tersebut menyebabkan pemborosan biaya praktikum.

Ditinjau dari hasil, kegiatan praktikum yang dilakukan tidak mampu menghasilkan suatu produk yang mempunyai nilai tambah. Hal ini disebabkan produk yang dihasilkan melalui kegiatan praktikum hanya mempunyai struktur dan kaulitas fungsional yang rendah sehingga produk tidak laku untuk dijual. Ditinjau dari konsep produksi, produk sebagai output dari proses produksi (kegiatan praktikum) tidak mengalami kenaikan nilai tetapi malah mengalami penurunan nilai. Sebagai contoh, produk hasil praktikum pemesinan hanya laku dijual sebagai barang bekas dengan harga yang sangat jauh dari harga material awalnya. Tentu saja ini merupakan suatu kerugian.

Permasalahan-permasalahan tersebut di atas merupakan indikasi kurang optimalnya program praktikum. Program praktikum yang telah dilaksanakan dapat dinilai tidak mampu mengembalikan investasi. Efeknya adalah banyaknya sarana dan prasarana sebagai contoh mesin-mesin yang rusak dan tidak dapat digunakan kembali apalagi untuk beregenerasi. Efek lain adalah berkurangnya kepercayaan masyarakat terhadap lembaga. Ada anggapan bahwa guru yang dihasilkan oleh UPI khususnya guru SMK adalah guru teori saja tetapi tidak kompeten dalam praktikum. Efek negatif tersebut tentu saja bukan yang kita kehendaki.

Diantara usaha untuk memecahkan permasalahan tersebut adalah diperlukan pengembangan model praktikum yang terintegrasi. Model praktikum yang dikembangkan diharapkan mampu mengintegrasikan semua kegiatan praktikum di JPTM untuk mendukung pencapaian kompetensi mahasiswa JPTM sebagai calon guru SMK. Dalam waktu selanjutnya kegiatan praktikum tersebut dirancang untuk menghasilkan produk yang dapat menghasilkan nilai tambah.

\section{Tujuan dan Manfaat}

Secara khusus tujuan penelitian ini adalah sebagai berikut :

1. Mendapatkan identifikasi jenis-jenis praktikum yang relevan untuk menunjang pencapaian kompetensi mahasiswa JPTM sebagai calon guru bidang teknik mesin berdasarkan tuntutan kurikulum SMK.

2. Menghasilkan rancangan pola sebaran mata kuliah praktikum yang dapat menunjang pencapaian kompetensi mahasiswa JPTM sebagai calon guru SMK.

3. Menghasilkan rumusan kompetensi mahasiswa sebagai calon guru praktikum bidang teknik mesin berdasarkan tuntutan kurikulum SMK.

Hasil penelitian ini sangat bermanfaat untuk meningkatkan efektifitas, efisiensi, akuntabilitas, dan relevansi pelaksanaan program kegiatan praktikum di JPTM. Secara khusus manfaat penelitian ini adalah sebagai bahan evaluasi menyangkut relevansi kurikulum yang sekarang diterapkan di JPTM FPTK UPI dan sebagai bahan pertimbangan dalam pengadaan sarana dan prasarana praktikum bagi mahasiswa di JPTM FPTK UPI. Dalam jangka menengah hasil penelitian ini dapat dijadikan landasan dalam pengembangan unit produksi di JPTM FPTK UPI.

\section{Metodologi}

Penelitian ini merupakan penelitian pengembangan yang akan menggunakan metode deskriptif. Namun mengingat keterbatasan waktu dan biaya penelitian, penelitian ini dibatasi hanya sampai pada tahap menghasilkan draf desain model (model hipotetik), yaitu model yang dihasilkan berdasarkan kajian para ahli dalam Focus Group Discusion.

Data yang diperlukan dalam penelitian ini meliputi data jenis-jenis praktikum, standar kompetensi siswa SMK dalam praktikum pada program teknik mesin, dan data mata kuliah praktikum di JPTM FPTK UPI kelompok bidang keahlian Produksi dan Perancangan. Data yang diperlukan diperoleh melalui studi dokumentasi. Sumber data meliputi kurikulum SMK bidang teknik mesin dan kurikulum JPTM FPTK UPI kelompok bidang keahlian Produksi dan Perancangan serta dosen pengampu mata kuliah praktikum di JPTM FPTK UPI. Data yang telah terkumpul akan dianalisa untuk menghasilkan pola model praktikum terintegrasi dengan langkah-langkah sebagai berikut : 
1) Mengidentifikasi dan mengelompokkan data mata diklat praktikum bidang teknik mesin berdasarkan kurikulum SMK

2) Mengidentifikasi kompetensi ,kriteria unjuk kerja, dan jenis proses tiap mata diklat praktikum berdasarkan kurikulum SMK

3) Mengidentifikasi pola sebaran mata diklat praktikum berdasarkan kurikulum SMK.

4) Membuat pemetaan kompetensi guru praktikum bidang teknik mesin berdasarkan kurikulum SMK.

5) Mengidentifikasi mata kuliah praktikum di JPTM yang relevan dengan tuntutan kompetensi mahasiswa sebagai calon guru praktikum bidang teknik mesin di SMK.

6) Merancang pola sebaran mata kuliah praktikum bagi mahasiswa di JPTM.

7) Menetapkan materi praktikum pada mata kuliah praktikum yang relevan di JPTM.

8) Mengembangkan rumusan kompetensi dan kriteria unjuk kerja mata kuliah praktikum yang relevan di JPTM melalui Focus Group Discusion (FGD).

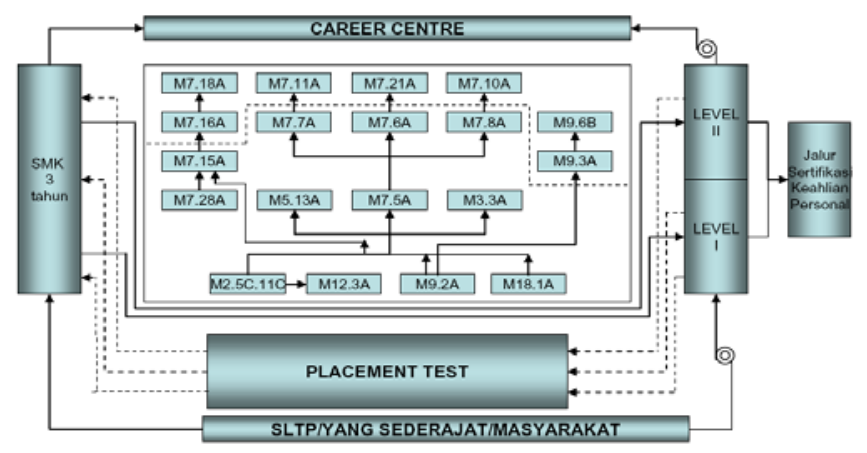

Gambar 1. Diagram pencapaian kompetensi SMK

Hasil dan Pembahasan

1. Deskripsi jenis praktikum bagi mahasiswa JPTM

Sejalan dengan tujuan penelitian, untuk mengidentifikasi jenis praktikum yang relevan bagi mahasiswa JPTM FPTK UPI khususnya bagi mahasiswa bidang keahlian produksi dan perancangan adalah dengan menganalisa jenis praktikum di SMK bidang teknik mesin. Jenis-jenis praktikum di SMK tersebut dapat dilihat pada kurikulum SMK khususnya pada diagram pencapaian kompetensi (gambar 1).

Berdasarkan diagram tersebut, terdapat sembilan belas kompetensi yang diharapkan dapat dipenuhi oleh lulusan SMK. Megacu pada kurikulum SMK, maka kurikulum 2007 yang sekarang dipergunakan merupakan pengembangan dari kurikulum 2004. Kurikulum 2007 atau lebih dikenal sebagai KTSP jika diamati sebenarnya mirip atau boleh dikatakan sama dengan KBK. Pada mata pelajaran/mata diklat produktif tetap masih menggunakan istilah kompetensi yang merupakan kata kunci KBK 2004. Ujung dari diagram adalah sertifikasi keahlian personal yang juga sama dengan KBK 2004. Hal lainnya adalah kesamaaan input dan output yang multi exit dan multi entry. Beberapa hal yang membedakan antara KTSP dengan KBK diantaranya adalah:

1. Jumlah dan macam kompetensi. Pada KTSP jumlah kompetensinya sebanyak 19 buah, sedangkan pada KBK sebanyak 16 buah. Perubahan jumlah ini sebenarnya merupakan pengembangan dari kompetensi yang telah ada dan penambahan kompetensi baru. Pengembangan kompetensi pada KTSP yaitu pada kompetensi yang berhubungan dengan mesin NC/CNC yang pada KBK hanya 2 kompetensi sedangkan pada KTSP menjadi 4 kompetensi. Kompetensi lain yang dikembangkan adalah kompetensi bidang gambar, dimana pada KTSP ditambah dengan kompetensi Merancang gambar teknik secara rinci. Sementara itu kompetensi baru yang ditambah pada KTSP adalah kompetensi melakukan pengelasan secara manual dan kompetensi Perakitan pelat dan lembaran. Penambahan kompetensi tersebut berimplikasi terhadap penghapusan beberapa kompetensi diantaranya adalah kompetensi Menggunakan mesin untuk operasi. Pengembangan kompetensi pada pemesinan NC/CNC mungin disebabkan oleh semakin meningkatnya penggunaan mesin perkakas berbasis CNC dibandingkan dengan mesin perkakas manual. Hal ini wajar karena mesin perkakas CNC mampu menghasikan produk dengan kualitas dan produktifitas yang lebih tinggi dibandingkan mesin perkakas manual. Pengembangan kompetensi perancangan gambar teknik dikarenakan adanya tuntutan lulusan SMK harus mampu merancang suatu produk yang lebih komplek dibandingkan hanya sekedar dapat membaca dan mengambar sketsa. Dengan demikian ada peningkatan kompetensi dalam perancangan. Sementara itu penambahan kompetensi melakukan pengelasan secara manual didasari oleh kenyataan bahwa pengelasan merupakan bagian integral dari suatu desain mesin juga terbukanya peluang untuk bekerja pada bagian pengelasan.

2. Penulisan kode. Semua kode kompetensi pada KTSP berbeda dengan KBK, dimana kode pada KTSP menggunakan gabungan antara huruf dan angka yang kesemuanya dimulai dengan huruf $\mathrm{M}$ capital sedangkan pada KBK mengunakan huruf saja yang berurutan dari A sampai P. Sebagai contoh kode kompetensi Membaca gambar teknik yang pada KBK menggunakan kode huruf A pada KTSP kodenya menjadi M9.2A. Namun kekurangan system pengkodean pada KTSP 
adalah bahwa kode yang disusun masih kurang menunjukkan urutan atau sekuen yang baku sehingga menyulitkan dalam memahaminya. Sebagai contoh kode M2.5C.11C adalah kode untuk kompetensi Mengukur dengan menggunakan alat ukur dan kode M12.3A adalah kode untuk kompetensi Mengukur dengan menggunakan alat ukur presisi. Jika dilihat dari diagram pencapaian kompetensi maka M2.5C.11C merupakan prasyarat bagi kompetensi M12.3A, sementara jika dilihat dari kodenya kedua kompetensi itu tidak menunjukan adanya kaitan. Mungkin sebaiknya pengkodean itu disusun berdasarkan sekuen kompetensinya.

3. Nama kompetensi. Penamaan suatu kompetensi pada KTSP jika dibandingkan dengan nama kompetensi pada KBK ada yang tetap sama, ada yang dikembangkan, dan ada yang baru. Contoh nama kompetensi yang masih tetap adalah kompetensi Membaca gambar teknik, mengguanakan perkakas tangan, dan lainnya. Sedangkan nama kompetensi yang dikembangkan contohnya adalah kompetensi Menggunakan alat ukur menjadi kompetensi Mengukur dengan menggunakan alat ukur. Sementara itu nama kompetensi baru adalah kompetensi yang memang pada KBK belum ada, contohnya adalah kompetensi Melakukan pengelasan secara manual.

\section{Pengelompokan kompetensi dan mata kuliah praktek di JPTM yang relevan}

Berdasarkan jenis kompetensi dan digram pencapaiannya, melalui penelitian ini kemudian dibuat pengelompokan kompetensi berdasarkan akar keilmuan atau kedekatan materi dari tiap-tiap kompetensi. Secara teoritik ke 19 kompetensi pada mata pelajaran produktif di SMK yang diteliti dapat dikelompokan menjadi empat kelompok kompetensi, yaitu kompetensi gambar, teknologi mekanik, pemesinan konvensional, dan pemesinan CNC. (Tabel 1). Dengan demikian pengembangan kompetensi kejuruan bagi mahasiswa JPTM FPTK UPI sebagai calon guru SMK selayaknya minimal didasarkan atas empat kompetensi utama tersebut. Kompetensi gambar, memungkinkan seseorang untuk menjadi ahli dalam bidang gambar/desain yaitu kemampuan dari membaca gambar teknik sampai pada kemampuan merancang gambar teknik. Gambar merupakan alat komunikasi utama bagi seorang yang bekerja di bidang teknik khususnya pada teknik mesin. Kunci komunikasi adalah sampainya pesan kepada penerima, dengan demikian kemampuan seseorang dalam gambar akan mempengaruhinya dalam menyampaikan maupun menerima pean dalam berkomunikasi tersebut. Oleh karena itu kompetensi ini sangat penting untuk dikuasai oleh mahasiswa khususnya mahasiswa teknik mesin.
Kompetensi pada kelompok praktek dasar menyangkut kompetensi yang berkaitan dengan kemampuan menggunakan alat ukur yang sesuai, kemampuan menggunakan alat-alat teknik produksi dasar untuk pengerjaan produk secara manual baik produk berupa benda solid maupun dari bahan yang berupa lembaran, juga kemmapuan mengunakan mesin yang sifatnya dasar seperti mesin gergaji, bor manual, las manual, dan sebagainya. Kompetensi ini perlu dikuasai oleh orang yang terlibat dalam proses produksi karena tidak semua produk dapat dikerjakan oleh mesin, juga kemampuan dalam bidang ini sangat bermanfaat untuk proses finishing suatu produk.

Kompetensi pemesinan konvensional, merupakan kompetensi pada teknik berproduksi dengan menggunakan mesin perkakas yang pengontrolannya masih bersifat manual. Jenis pemesinan ini meliputi pemesinan dengan menggunakan mesin bubut, frais, skraf, dan gerinda. Kompetensi ini merupakan dasar bagi seseorang untuk dapat memproduksi suatu produk dengan menggunakan mesin perkakas. Kompetensi ini penting karena kenyataan dilapangan industri-industri pemesinan di Indonesia sebagian besar masih menggunakan mesin perkakas manual. Keuntungan dari penggnaan mesin perkakas manual adalah selain dapat menyerap tenaga kerja yang lebih banyak juga lebih menguntungkan untuk proses produksi dalam jumlah sedikit tetapi variasi banyak. Dengan demikian kompetensi ini mutlak diperlukan oleh mahasiswa JPTM FPTK UPI baik sebagai calon guru SMK maupun jika bekerja di industri.

Tabel 1 Pengelompokan kompetensi

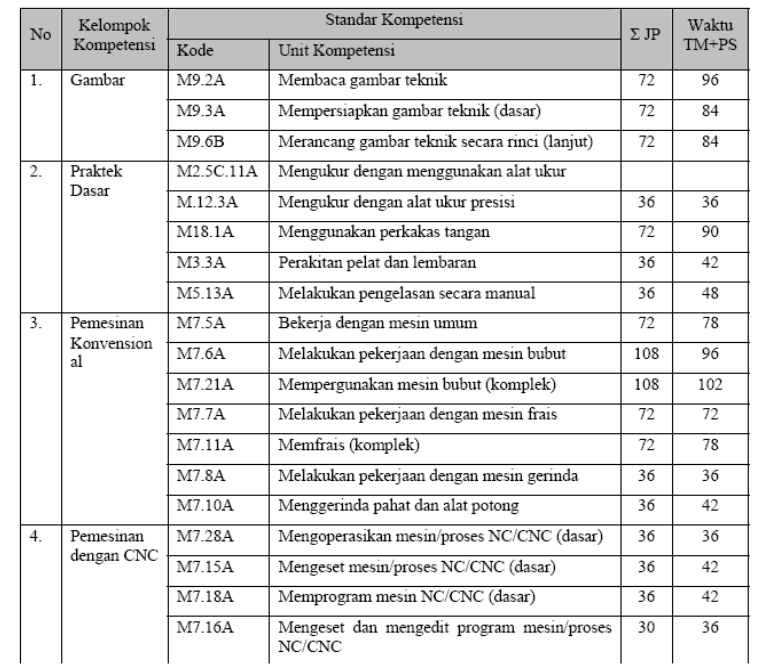

Kompetensi pemesinan CNC merupakan kompetensi yang sifatnya advance merupakan kelanjutan dari kompetensi pemesinan manual. Kompetensi ini menyangkut teknik berproduksi dengan menggunakan mesin perkakas yang dikontrol 
secara numeric oleh komputer. Kompetensi ini perlu dimiliki karena ada kecenderungan bahwa industri pemesinan mulai bergeser dari penggunaan mesin perkakas manual menjadi mesin perkakas CNC. Tidak hanya karena mesin CNC lebih tinggi tingkat kualitas produk yang dihasilkannya tetapi juga karena harganya yang semakin murah.

Mengacu pada pengelompokan kompetensi tersebut kemudian diidentifikasi lalu dibandingkan dengan mata kuliah praktikum yang mempunyai relevansi di JPTM FPTK UPI pada bidang keahlian produksi dan perancangan. Hasil identifikasi tersebut sebagaimana diperlihatkan pada tabel 2 .

Tabel 2. Mata kuliah praktek di JPTM yang relevan dengan kebutuhan SMK

\begin{tabular}{|c|c|c|c|c|c|}
\hline \multirow{2}{*}{ No. } & \multirow{2}{*}{ Kelompok Kompetensi } & \multicolumn{3}{|c|}{ Mata Kuliah } & \multirow{2}{*}{$\begin{array}{l}\text { Alokasi } \\
\text { Waktu }\end{array}$} \\
\hline & & Kode & Nama & SKS & \\
\hline \multirow[t]{2}{*}{1.} & \multirow[t]{2}{*}{ Gambar } & PP 210 & Gambar Teknik & 2 & 53,33 \\
\hline & & PP 451 & Auto CAD dan Gambar Merencana & 2 & 53,33 \\
\hline \multirow[t]{3}{*}{2.} & \multirow[t]{3}{*}{ Praktek Dasar } & PP 221 & Fabrikasi Logam & 3 & 80 \\
\hline & & PP 241 & Teknik Penyambungan & 3 & 80 \\
\hline & & \begin{tabular}{|l|l|} 
PP 251 \\
\end{tabular} & Teknik Pembentukan & 2 & 53,33 \\
\hline 3. & $\begin{array}{l}\text { Pemesinan Konvensional } \\
\end{array}$ & PP 253 & Teknik Pemesinan & 2 & 53,33 \\
\hline 4. & Pemesinan dengan $\mathrm{CNC}$ & PP 471 & Teknik Pemesinan CNC & 4 & 106,67 \\
\hline
\end{tabular}

Berdasarkan data tersebut, terdapat beberapa hal yang dapat dijelaskan sebagai berikut :

1. Mata kuliah yang relevan dengan tuntutan kompetensi di SMK hanya berjumlah 7 buah atau hanya 9\% dari total mata kuliah dengan bobot 18 SKS atau hanya sebesar $11.69 \%$ dari total SKS yang harus diselesaikan oleh mahasiswa S-1. Sedangkan untuk SMK jumlah mata pelajaran kompetensi kejuruan mencapai 18 buah atau sebesar $45.4 \%$ dari total mata pelajaran dengan bobot $1044 \mathrm{JP}$ atau setara dengan 23,67 \% dari jumlah total jam pelajaran. Ketimpangan jumlah mata kuliah praktikum kejuruan ini berkaitan pula dengan meteri/ kompetensi kejuruan yangdimiliki oleh lulusan JPTM. Ketimpangan kompetensi ini diindikasikan menjadi penyebab lemahnya lulusan JPTM FPTKUPI untuk mengajar mata kuliah praktek kejuruan di SMK.

2. Alokasi waktu mata kuliah praktikum di JPTM FPTK UPI jika dibandingkan dengan di SMK hanya sebesar $42,32 \%$. Kondisi ini menunjukkan bahwa mahasiswa kurang mendapat kesempatan untuk berlatih dalam kegiatan praktikum kejuruan.

Sebagaimana kita ketahui bahwasannya salah satu faktor suksesnya pelatihan skill adalah intensifikasi pelatihan yang dilakukan seseorang. Dengan demikian ketidak cukupan alokasi waktu yang disediakan bagi mahasiswa untuk berlatih dalam kegiatan praktikum mengakibatkan mahasiswa kurang mempunyai keterampilan dalam praktek sehingga mengurangi kesiapan mereka untuk menjadi guru di SMK khususnya guru pada mata pelajaran praktek/produktif.

Alokasi waktu menunjukkan lamanya seseorang mempelajari materi tertentu sampai dia menguasai suatu kompetensi tersebut. Meskipun pada pelatihan berbasis kompetensi tujuan utama adalah pencapain kompetensi dan bukan pada lamanya pelatihan, tetapi pelatihan apapun harus memperhatikan waktu minimal dan waktu maksimalnya agar program dapat direncanakan dan dilaksanakan secara efektif dan effisien.

\section{Pengembangan mata kuliah praktek kejuruan di JPTM}

Berdasarkan data pada tabel di atas terlihat bahwa terdapat kesenjangan antara kompetensi dan alokasi waktu pelaksanaan mata kuliah praktek kejuruan di JPTM FPTK UPI dengan yang dilakukan oleh siswa. Dengan demikian diperlukan pengembangan mata kuliah di JPTM FPTK UPI khususnya terutama pada kelompok kopetensi gambar dan pemesinan konvensional

Pengembangan yang dilakukan dalam penelitian ini meliputi penambahan materi kuliah, penambahan alokasi waktu untuk kegiatan praktek dan pola sebaran mata kuliah praktek kejuruan (tabel $3)$.

Tabel 3. Pengembangan mata kuliah praktek kejuruan di JPTM

\begin{tabular}{|c|c|c|c|c|c|c|}
\hline \multirow{2}{*}{ No. } & \multirow{2}{*}{ Kompetensi } & \multicolumn{5}{|c|}{ Mata Kuliah } \\
\hline & & Kode & Nama & Bobot & Smt & Ket. \\
\hline \multirow[t]{3}{*}{1.} & \multirow[t]{3}{*}{ Gambar } & PP 210 & Gambar Teknik & 2 & 1 & Tambah materi \\
\hline & & PP 220 & Auto CAD & 3 & 2 & Tambah MK \\
\hline & & PP 451 & Gambar Merencana & 3 & 5 & Tambah materi \\
\hline \multirow[t]{3}{*}{2.} & \multirow[t]{3}{*}{ Praktek dasar } & PP 221 & Fabrikasi Logam & 3 & 2 & Tetap \\
\hline & & PP 241 & Teknik Penyambungan & 3 & 4 & Tetap \\
\hline & & PP 251 & Teknik Pembentukan & 2 & 5 & Tetap \\
\hline \multirow[t]{2}{*}{3.} & \multirow{2}{*}{$\begin{array}{l}\text { Pemesinan } \\
\text { Konvensional }\end{array}$} & PP 231 & Teknik Pemesinan I & 4 & 3 & Tambah materi \\
\hline & & PP 452 & Teknik Pemesinan II & 4 & 4 & Tambah MK \\
\hline \multirow[t]{2}{*}{4.} & \multirow{2}{*}{$\begin{array}{l}\text { Pemesinan } \\
\text { CNC }\end{array}$} & PP 261 & Pemesinan CNC I & 2 & 6 & Tambah materi \\
\hline & & PP 472 & Pemesinan CNC II & 3 & 7 & Tambah MK \\
\hline
\end{tabular}
kompetensi gambar dan pemesinan CNC, sedangkan penambahan materi dan alokasi waktu diperuntukan bagi kompetensi pemesinan konvensional. Untuk kompetensi Teknologi Mekanik materi yang diberikan telah memenuhi tingkat relevansi yang tinggi.

Pengembangan ini membawa konsekwensi, yaitu penambahan alokasi waktu kuliah atau penambahan jumlah SKS dari SKS semula. Perlu dicermati dan difikirkan bahwasannya jumlah SKS standar bagi mahasiswa S-1 adalah 144 SKS. Dengan demikian penambahan SKS pada mata kuliah praktek menyebabkan perubahan alokasi waktu untuk mata kuliah yang lain. 
Jumlah mata kuliah praktek kejuruan telah ditingkatkan dari semula 7 buah menjadi 10 buah. Alokasi waktu untuk 10 mata kuliah tersebut sebesar 29 SKS atau setara dengan 773 jam. Alokasi waktu ini jika dibandingkan dengan alokasi waktu pelatihan di SMK setara dengan 74,1 \% atau mengalami peningkatan sebesar 31,78\%.

Peningkatan alokasi waktu ini diharapkan dapat memberikan kesempatan yang lebih banyak kepada mahasiswa untuk berlatih guna meningkatkan skillnya yang dapat menunjang peningkatan kompetensinya khususnya kompetensi kejuruan. Dalam implementasinya nanti penambahan alokasi waktu ini harus diimbangi dengan ketersediaan sarana dan prasarana yang digunakan mahasiswa dalam praktikum dengan jumlah yang memadai. Dengan kata lain rasio antara alat praktikum dengan mahasiswa sesuai dengan standart. Jika kondisi yang diharapkan dapat diwujudkan, hal ini akan meningkatkan efektifitas dan effisiensi pelaksanaan program praktikum yang telah dirancang.

Diwaktu selanjutnya mahasiswa yang dihasilkan dari program praktikum yang dirancang ini akan meningkat kompetensi kejuruannya sehingga akan semakin menambah kesiapan mereka untuk terjun di dunia pendidikan sebagai guru praktikum kejuruan di SMK.

\section{Simpulan dan saran}

Beberapa kesimpulan yang dapat ditarik dari hasil penelitian ini adalah :

1. Jenis praktikum yang relevan untuk menunjang pencapaian kompetensi mahasiswa JPTM bidang keahlian produksi dan perancangan sebagai calon guru SMK bidang teknik mesin terdiri atas 19 jenis praktikum yang dikelompokkan menjadi 4 kelompok kompetensi praktikum yang meliputi kompetensi gambar, praktek dasar, pemesinan konvensional, dan pemesinan CNC.

2. Telah dihasilkan rancangan pengembangan dan pola sebaran mata kuliah praktek kejuruan untuk JPTM FPTK UPI. Pengembangan meliputi penambahan materi, penambahan mata kuliah, dan penambahan alokasi waktu praktek sebesar $31,78 \%$. Sebaran mata kuliah praktek yang dirancang adalah : Kompetensi Gambar berada pada semester 1,2, dan 5, kompetensi Praktek Dasar berada pada semester 2,4,dan 5, kompetensi Pemesinan Konvensional berada pada semester 3 dan 4, dan kompetensi Pemesinan CNC berada pada semester 6 dan 7 .

Beberapa saran yang dapat dikemukakan berkenaan dengan hasil penelitian adalah sebagai berikut :

1. Bagi pihak SMK hendaknya pengkodean kompetensi disempurnakan kembali dengan sistem pengkodean yang mudah dipahami dan dapat menunjukkan hubungan antara kompetensi serta adanya sekuen yang logis.

2. Bagi pihak JPTM FPTK UPI agar senantiasa melakukan evaluasi khususnya menyangkut relevansi kurikulum yang dikembangkannya dengan kebutuhan. SMK sehingga mampu menghasilkan kurikulum yang mempunyai relevansi yang tinggi dengan kebutuhan penggunanya.

3. Bagi penelitian selanjutnya perlu dikembangkan penelitian menyangkut evaluasi implementasi mata kuliah praktikum kejuruan yang dihasilkan dalam penelitian iniyang bermanfaat bagi pengembangan berikutnya.

\section{Daftar Pustaka}

Arikunto S. (1988). Perencanaan dan Pengembangan Kurikulum Pendidikan Teknologi dan Kejuruan. Jakarta: P2LPTK

DeGarmo Paul, (1990), Material and Processes in Manufacturing $7^{\text {th }}$ edition, New York : Macmillan Publishing Company.

Depdiknas,(2001), Kurikulum Berbasis Kompetensi Kebijaksanaan Umum, Pusat Kurikulum Badan Penelitian dan pengembangan Jakarta : Departemen Pendidikan Nasional.

Evans, Rupert N. (1971). Foundation of vocational education. Columbus: Charles E. Merril Publishing Co.

Indonesian Partnership for Skills Development Program (2001), Competency- Based Training, Sydney : AusAID.

Indonesian Partnership for Skills Development Metal Project, (2001), Competency-Based Training and Assessment Awareness Program, Sydney : AusAID.

Jusuf, Eddy (2001), Peranan Dunia Pendidikan dalam Mengembang-kan Dunia Usaha Pada Era Otonomi Daerah (makalah), Bandung : FPTKUPI

Lembaga Sertifikasi Profesi Logam dan Mesin Indonesia, (2002), Standar Kompetensi Kerja Nasional Indonesia Industri Logam dan Mesin, Buku 1 dan 2.

Nana Syaodih S., 2000, Pengembangan Kurikulum Teori dan Praktek, Bandung : PT Remaja Rosda Karya. - 1988, Prinsip dan Landasan Pengembangan Kurikulum, Jakarta : P2LPTK Depdikbud.

Nasution S.,1999, Kurikulum dan Pengajaran, Bandung : Bumi Aksara

Rochim, T. (1993), Teori dan Teknologi Proses Pemesinan, Jakarta : Higher Education Development Support Project.

Suryadi A.(2001), Kebijakan Pendidikan Nasional (makalah), Bandung : FPTK-Universitas Pendidikan Indonesia. 
Suzaki, K. (1993), The New Shop Floor Management, New York : The Free Press.

Thompson, John F. (1973). Foundation of vocational education. New Jersey: Prentice-Hall, Inc.

Thorogood, Ray. (1982). Current themes in vocational education and training polices: Part I. Industrial and Commercial Training.

Wenrich, Ralph C. dan J. William Wenrich. (1974). Leadership in administration of vocational and technical education. Columbus: Charles E. Merril Pub. Co.

Yuwana,Y.M.(2000). Sistem Produksi, Bandung : Jurusan Teknik Mesin FTI, ITB 